\title{
Gejala Gastrointestinal pada Pasien COVID-19
}

\author{
Kristianty T. Silangen, ${ }^{1}$ Bradley J. Waleleng, ${ }^{2}$ Frans E. N. Wantania ${ }^{2}$
}

\author{
${ }^{1}$ Program Studi Pendidikan Dokter Fakultas Kedokteran Universitas Sam Ratulangi, \\ Manado, Indonesia \\ ${ }^{2}$ Bagian Ilmu Penyakit Dalam Fakultas Kedokteran Universitas Sam Ratulangi Manado, \\ Indonesia \\ Email: ksilangen@icloud.com
}

\begin{abstract}
Patients suffering from corona virus desease of 2019 (COVID-19) could have gastrointestinal symptoms such as diarrhea, vomiting, and stomach pain. Studies show that human receptor for COVID-19 namely the angiotensin-converting enzyme 2 (ACE2) receptors are also expressed in small intestinal epithelial cells. This study was aimed to determine the gastrointestinal symptoms often found in patients with COVID-19. This was a literature review study using databases of Google Scholar, the keywords were ("Covid" AND "gastrointestinal symptoms"), and filtering data by time 2019-2020. The results obtained 10 literatures that fulfilled the inclusion and exclusion criteria. The review obtained that viral infection causes changes in intestinal permeability. SARS-CoV was also identified in ileal and terminal colon biopsy. Gastrointestinal symptoms are accompanied by inflammation of the intestines. The highest percentage of gastrointestinal symptoms were anorexia, followed by diarrhea, nausea/vomiting, abdominal pain. Gastrointestinal symptoms could be the first symptoms or even the only symptoms that appeared in Covid-19 patients. Gastrointestinal symptoms were also associated by impaired hepatic function. In conclusion, gastrointestinal symptoms in Covid-19 patients had a relatively high prevalence, and often appeared as anorexia, diarrhea, nausea/vomiting, and abdominal pain. Some of these symptoms were related to the severe course of Covid-19. Impaired liver function also exacerbated these symptoms as well as a marker of a poor clinical course of Covid-19.
\end{abstract}

Keywords: COVID-19, gastrointestinal symptoms

\begin{abstract}
Abstrak: Penderita COVID-19 dapat disertai gejala gastrointestinal seperti diare, muntah, dan sakit perut. Studi menunjukkan bahwa reseptor manusia untuk COVID-19 yaitu reseptor angiotensin-converting enzyme 2 (ACE2) diekspresikan juga dalam sel epitel usus kecil. Penelitian ini bertujuan untuk mengetahui gejala gastrointestinal yang sering ditemukan pada pasien dengan COVID-19. Jenis penelitian ialah literature review yang menggunakan database Google Cendekia, dan kata kunci ("Covid" DAN "gejala gastrointestinal") dengan filter rentang waktu tahun 2019-2020 Hasil penelitian mendapatkan 10 literatur yang memenuhi kriteria inklusi dan eksklusi penelitian. Kajian mendapatkan infeksi virus menyebabkan perubahan permeabilitas usus. SARS-CoV juga diidentifikasi pada biopsi ileum dan kolon terminal. Masalah usus dikaitkan dengan tingkat keparahan infeksi. Gejala gastrointestinal disertai dengan peradangan atau kerusakan usus. Beberapa penelitian menunjukkan persentase gejala gastrointestinal tertinggi ialah anoreksia, diikuti diare, mual/muntah, dan terakhir nyeri perut. Juga disebutkan bahwa gejala gastrointestinal dapat merupakan yang pertama muncul atau bahkan satu-satunya gejala pada pasien Covid-19. Gejala gastrointestinal juga dikaitkan dengan gangguan fungsi hati. Simpulan penelitian ini ialah gejala gastrointestinal pada pasien Covid-19 memiliki prevalensi yang relatif tinggi dan sering berupa anoreksia, diare, mual/muntah, dan nyeri perut. Beberapa gejala tersebut berhubungan dengan perjalanan Covid-19 yang berat. Gangguan fungsi hati juga turut memperberat gejala tersebut sekaligus menjadi penanda perjalanan klinis yang buruk dari Covid-19.
\end{abstract}

Kata kunci: COVID-19, gejala gastrointestinal 


\section{PENDAHULUAN}

Severe Acute Respiratory Syndrome Coronavirus-2 (SARS-CoV-2) adalah virus corona baru $(\mathrm{CoV})$ yang sebelumnya tidak dikenal masyarakat. Virus ini diklasifikasikan sebagai beta-CoV dari grup 2B dan merupakan penyebab penyakit serius yang mengancam jiwa yang dikenal sebagai Corona Virus Desease of 2019 (COVID19). ${ }^{1}$ Penyakit novel coronavirus 2019 (COVID-19) pertama kali muncul pada bulan Desember 2019, di Wuhan, China dan berkembang menjadi pandemi. Penyakit ini ditularkan melalui penghirupan atau kontak dengan tetesan yang terinfeksi dengan masa inkubasinya berkisar antara 2-14 hari. Gejalanya biasanya berupa demam, batuk, sakit tenggorokan, sesak napas, kelelahan, malaise. ${ }^{2,3}$ Menurut laporan World Health Organization (WHO) pada September 2020, terdapat hampir 33 juta kasus yang terinfeksi dan 980.000 kematian telah dilaporkan secara global. ${ }^{4}$ Indonesia melaporkan kasus pertama pada tanggal 2 Maret 2020. Kasus meningkat dan menyebar dengan cepat di seluruh wilayah Indonesia. Sampai dengan tanggal 25 September 2020 Kementerian Kesehatan Indonesia melaporkan 266.845 kasus konfirmasi COVID-19 dengan 60.431 kasus aktif dan 10.218 kasus meninggal (CFR 3,8\%). Di Sulawesi Utara sendiri, tercatat 4.390 kasus konfirmasi COVID-19 dengan 755 kasus aktif dan 172 kasus meninggal (CFR 1,9\%). ${ }^{5}$

Sebagian pasien dengan COVID-19 mengalami gejala gastrointestinal (GI) seperti diare, muntah, dan sakit perut. Selain itu, berbagai studi melaporkan bahwa reseptor manusia untuk COVID-19 yaitu reseptor angiotensin-converting enzyme 2 (ACE2) diekspresikan dalam sel epitel usus kecil. ${ }^{6}$ Kasus pertama SARS-CoV-2 di Amerika Serikat melaporkan riwayat mual dan emesis selama dua hari, kemudian diare pada hari ke-2 masuk rumah sakit. Ditemukan juga adanya RNA SARS-CoV-2 dalam tinja beberapa pasien COVID-19 bahkan setelah pembersihan virus di saluran napas bagian atas. ${ }^{7}$
SARS-CoV-2 dapat secara aktif menginfeksi dan bereplikasi di saluran cerna, dengan implikasi penting untuk manajemen penyakit, penularan dan pengendalian infeksi. ${ }^{6}$ Berdasarkan latar belakang yang telah dipaparkan, terdapat berbagai faktor yang berkaitan antara COVID-19 dengan gejala gastrointestinal. Hal ini mendorong penulis untuk mengevaluasi gejala gastrointestinal yang sering terjadi pada pasien dengan COVID-19.

\section{METODE PENELITIAN}

Penelitian ini merupakan suatu literature review dengan pencarian literatur menggunakan database Google Cendekia/Google Scholar, dan filter yang tersedia yaitu filter rentang waktu dari tahun 2019-2020 dengan menuliskan kata kunci ("Covid" DAN "gejala gastrointestinal"). Dalam pencarian menggunakan database Pubmed dan Clinical Key, kata kunci dituliskan dalam bentuk ("covid" [Title/Abstract]) AND ("gastro intestinalsymptoms"[Title/Abstract]) menggunakan filter rentang waktu dari tahun 2019-2020.

Literatur yang diperoleh dari tiga database yang digunakan berjumlah 637 dari PubMed, 937 dari ClinicalKey, dan 29 dari Google Scholar $(\mathrm{n}=1.603)$ yang sesuai dengan kata kunci tersebut. Hasil pencarian yang sudah didapat kemudian disaring berdasarkan abstrak yang sesuai didapatkan 53 literatur. Selanjutnya literatur disaring lagi berdasarkan kriteria inklusi dan eksklusi, dan didapatkan 10 literatur untuk digunakan dalam penelitian ini.

\section{HASIL PENELITIAN}

Pencarian artikel dikumpulkan dari database jurnal online, yaitu google scholar, PubMed, dan Science Direct. Berdasarkan proses pencarian, didapatkan artikel sebanyak 1.603 artikel. Artikel yang diperoleh kemudian diseleksi kembali, diuraikan pada diagram prisma, dan didapatkan 10 artikel yang dianalisis secara mendalam. Tabel 1 memperlihatkan hasil kajian artikel yang dipakai dalam penelitian ini. 
Tabel 1. Hasil kajian literatur yang dipakai dalam penelitian

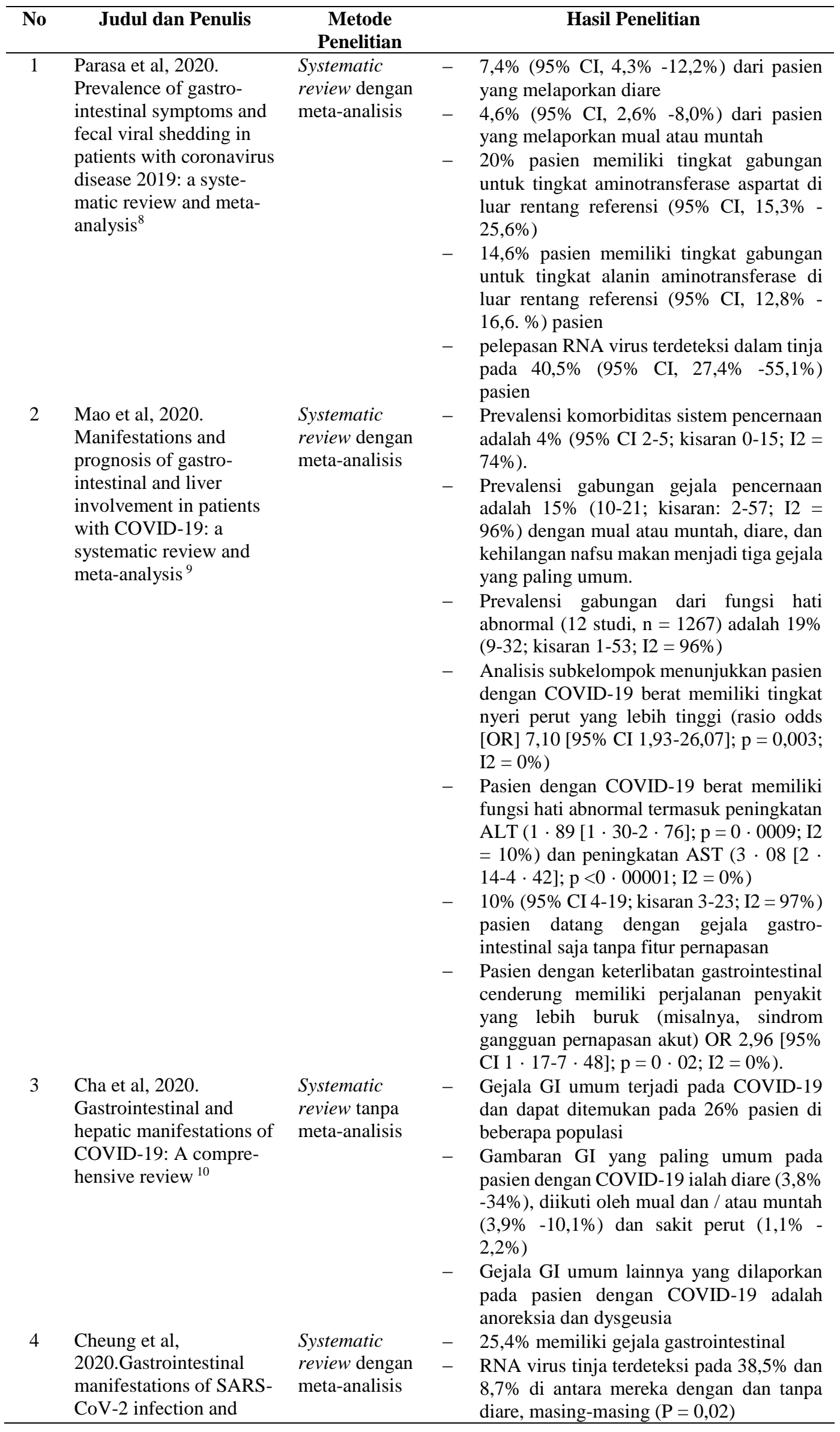




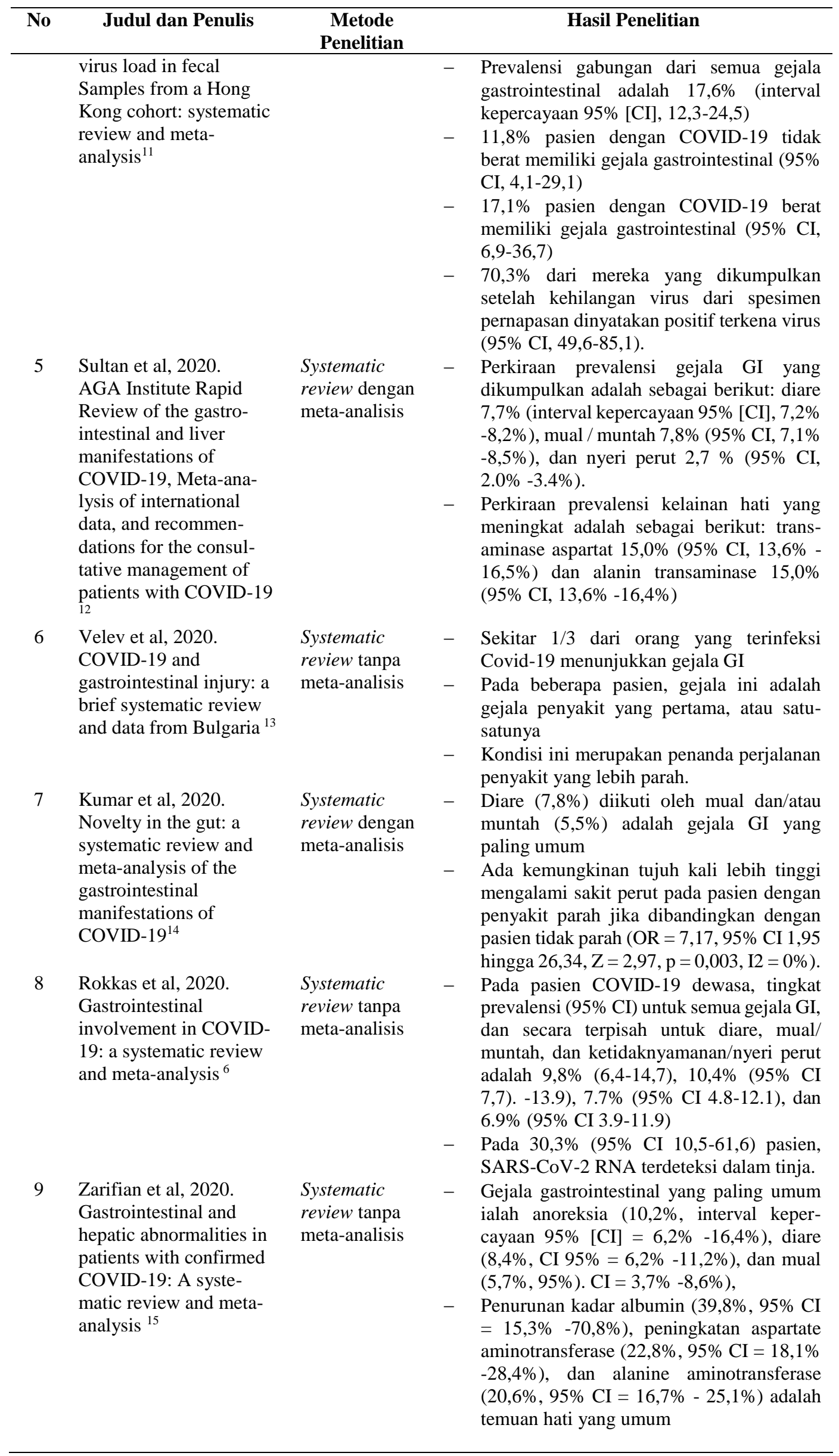




\begin{tabular}{|c|c|c|c|}
\hline No & Judul dan Penulis & $\begin{array}{l}\text { Metode } \\
\text { Penelitian }\end{array}$ & Hasil Penelitian \\
\hline 10 & $\begin{array}{l}\text { Tariq et al, } 2020 \text {. } \\
\text { Prevalence and mortality } \\
\text { of COVID-19 patients } \\
\text { with gastrointestinal } \\
\text { symptoms: a systematic } \\
\text { review and meta- } \\
\text { analysis }^{16}\end{array}$ & $\begin{array}{l}\text { Systematic } \\
\text { review dengan } \\
\text { meta-analisis }\end{array}$ & 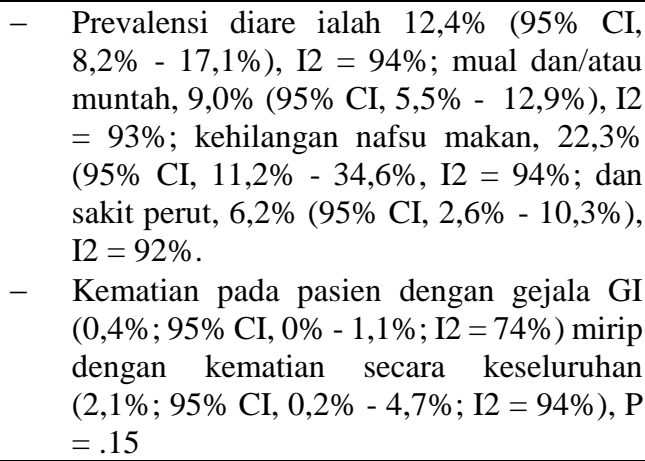 \\
\hline
\end{tabular}

Tabel 2 memperlihatkan adanya gejala diare yang didapatkan pada tujuh laporan penelitian yang dianalisis dalam bentuk persentase.

Tabel 2. Persentase gejala diare pada pasien Covid-19

\begin{tabular}{lc}
\hline \multicolumn{1}{c}{ Peneliti } & $\begin{array}{c}\text { Persentase } \\
\text { gejala diare }\end{array}$ \\
\hline Cha $(2020)^{10}$ & $3,8-34$ \\
Parasa $(2020)^{8}$ & 7,4 \\
Sultan $(2020)^{12}$ & 7,7 \\
Kumar $(2020)^{14}$ & 7,8 \\
Zarifian $(2020)^{15}$ & 8,4 \\
${\text { Rokkas }(2020)^{6}}_{\text {Tariq }^{15}(2020)^{16}}$ & 9,8 \\
Rerata & 12,4 \\
\hline
\end{tabular}

Tabel 3 memperlihatkan gejala mual/ muntah yang didapatkan pada tujuh laporan penelitian yang dianalisis dalam bentuk persentase.

Tabel 3. Persentase gejala mual/muntah pada pasien Covid-19

\begin{tabular}{lc}
\hline \multicolumn{1}{c}{ Peneliti } & $\begin{array}{c}\text { Persentase gejala } \\
\text { mual/muntah }\end{array}$ \\
\hline Cha $(2020)^{10}$ & $3,9-10,1$ \\
Parasa $(2020)^{8}$ & 4,6 \\
Kumar $(2020)^{14}$ & 5,5 \\
Zarifian $(2020)^{15}$ & 5,7 \\
Sultan $(2020)^{12}$ & 7,8 \\
Tariq $(2020)^{16}$ & 9,0 \\
${\text { Rokkas }(2020)^{6}}_{\text {Rerata }}$ & 10,4 \\
\hline
\end{tabular}

Tabel 4 memperlihatkan adanya gejala nyeri perut pada empat laporan penelitian yang dianalisis dalam bentuk persentase.
Tabel 4. Persentase gejala nyeri perut pada pasien Covid-19

\begin{tabular}{lc}
\hline \multicolumn{1}{c}{ Peneliti } & $\begin{array}{c}\text { Persentase gejala } \\
\text { nyeri perut }\end{array}$ \\
\hline Cha $(2020)^{10}$ & $1,1-2,2$ \\
Sultan $(2020)^{12}$ & 2,7 \\
Tariq $(2020)^{16}$ & 6,2 \\
Rokkas $(2020)^{6}$ & 6,9 \\
Rerata & 4,2 \\
\hline
\end{tabular}

Tabel 5 memperlihatkan adanya gejala anoreksia yang ditemukan pada dua laporan penelitian yang dianalisis dalam bentuk persentase.

Tabel 5. Persentase gejala anoreksia pada pasien Covid-19

\begin{tabular}{lc}
\hline \multicolumn{1}{c}{ Peneliti } & $\begin{array}{c}\text { Persentase gejala } \\
\text { anoreksia }\end{array}$ \\
\hline Zarifian $(2020)^{15}$ & 10,2 \\
Tariq $(2020)^{16}$ & 22,3 \\
Rerata & 16,2 \\
\hline
\end{tabular}

Tabel 6 memperlihatkan adanya gangguan fungsi hati yang didapatkan pada empat laporan penelitian yang dianalisis dalam bentuk persentase.

\section{BAHASAN}

Dari 10 laporan penelitian hasil scoping terdapat empat laporan penelitian yang melaporkan prevalensi kumulatif dari terjadinya gejala GI pada pasien Covid-19. Penelitian yang dilakukan oleh Mao et $\mathrm{al}^{9}$ mendapatkan prevalensi yang rendah, yaitu 4\% dari seluruh pasien Covid-19 namun tiga penelitian lain menunjukkan prevalensi yang jauh lebih tinggi. 
Tabel 6. Persentase gangguan fungsi hati pada pasien Covid-19

\begin{tabular}{cccc}
\hline Peneliti & $\begin{array}{c}\text { Peningkatan } \\
\text { SGOT } \\
(\boldsymbol{\%})\end{array}$ & $\begin{array}{c}\text { Peningkatan } \\
\text { SGPT } \\
(\boldsymbol{\%})\end{array}$ & $\begin{array}{c}\text { Penurunan } \\
\text { albumin } \\
(\boldsymbol{\%})\end{array}$ \\
\hline Mao $(2020)^{9}$ & 19 & 19 & - \\
Parasa $(2020)^{8}$ & 20 & 14,6 & - \\
Sultan $(2020)^{12}$ & 15 & 15 & - \\
Zarifian $(2020)^{15}$ & 22,8 & 20,6 & 39,8 \\
\hline
\end{tabular}

Penelitian yang dilakukan oleh Cheung et $\mathrm{al}^{11}$ menyebutkan prevalensi sebesar $25,4 \%$ dari seluruh pasien Covid-19 dan penelitian Cha et $\mathrm{al}^{10}$ dengan prevalensi sebesar $26 \%$ dari seluruh pasien Covid-19. Prevalensi tertinggi didapatkan pada penelitian Velev et $\mathrm{al}^{13}$ yang mendapatkan bahwa $33 \%$ pasien Covid-19 mengalami gejala GI. Penelitian tersebut juga menyebutkan bahwa gejala GI dapat merupakan gejala yang pertama muncul atau bahkan satu-satunya gejala yang muncul pada pasien Covid-19. Penelitian Tariq et al ${ }^{16}$ melaporkan bahwa mortalitas pada pasien Covid-19 dengan gejala GI relatif sama dengan pasien Covid19 tanpa gejala GI.

Beberapa penelitian menunjukkan gejala GI yang dapat muncul pada pasien Covid19. Penelitian yang dilakukan oleh Mao et $\mathrm{al}^{9}$ mendapatkan bahwa $15 \%$ pasien akan mengalami gejala GI yang terdiri dari mual/muntah, diare, dan anoreksia. Sejalan dengan hasil tersebut, penelitian Cheung et $\mathrm{al}^{11}$ juga mendapatkan gejala yang sama, tetapi dengan prevalensi yang lebih tinggi, yaitu $17,6 \%$.

Persentase gejala GI tertinggi ialah anoreksia, diikuti diare, mual/muntah, dan nyeri perut. Meskipun prevalensinya rendah, nyeri perut lebih mungkin ditemukan pada pasien Covid-19 yang berat. Penelitian Mao et $\mathrm{al}^{9}$ mendapatkan nilai odds ratio sebesar 7,1 yang berarti pasien dengan Covid-19 berat memiliki kemungkinan 7,1 kali lipat lebih besar untuk mengalami nyeri perut dibandingkan pasien Covid-19 tidak berat. Mendukung hasil tersebut, penelitian Kumar et $\mathrm{al}^{14}$ juga mendapatkan hasil yang nyaris sama, yaitu pasien dengan Covid-19 berat memiliki kemungkinan 7 kali lipat lebih besar untuk mengalami nyeri perut dibandingkan pasien Covid-19 tidak berat.

Penelitian yang dilakukan oleh Mao et $\mathrm{al}^{9}$ mendapatkan bahwa pasien dengan gejala GI memiliki kemungkinan tiga kali lipat lebih besar untuk mengalami perjalanan penyakit yang berat, seperti acute respiratory distress syndrome (ARDS). Mendukung hasil tersebut, penelitian oleh Cheung et $\mathrm{al}^{11}$ melaporkan bahwa sebanyak $17,1 \%$ pasien Covid-19 berat memiliki gejala GI. Angka ini lebih tinggi daripada pasien Covid-19 tidak berat, yaitu hanya sebesar $11,8 \%$. Velev et al $^{13}$ juga menyatakan bahwa gejala GI merupakan penanda penyakit Covid-19 berat. Gejala GI saja tanpa adanya gejala pernapasan juga dapat ditemukan pada $10 \%$ kasus Covid-19 sebagaimana yang dilaporkan oleh Mao et al. ${ }^{9}$

Hasil pemeriksaan RNA positif pada tinja didapatkan pada tiga laporan penelitian. Penelitian oleh Rokkas et $\mathrm{al}^{6}$ melaporkan bahwa 30,3\% pasien Covid-19 memiliki hasil RNA positif dari sampel tinja. Parasa et $\mathrm{al}^{8}$ mendapatkan hasil yang lebih tinggi, yaitu 40,5\% pasien Covid-19 memiliki hasil RNA positif dari sampel tinja. Berbeda halnya dengan Cheung et al ${ }^{11}$ yang membagi hasil penelitian berdasarkan ada tidaknya keluhan diare dan mendapatkan bahwa sebanyak 38,5\% pasien Covid-19 yang mengalami diare akan memiliki hasil RNA positif dari sampel tinja, sedangkan pada pasien Covid-19 yang tidak mengalami diare, persentasenya hanya $8,7 \%$.

Gejala GI juga dikaitkan dengan adanya gangguan pada fungsi hati. Tingginya kadar SGOT dan/atau SGPT menyebabkan munculnya berbagai gejala GI, seperti mual/ muntah dan anoreksia. Persentase gangguan 
fungsi hati pada pasien Covid-19 relatif tinggi. Penelitian oleh Mao et $\mathrm{al}^{9}$ juga menyebutkan bahwa gangguan fungsi hati berhubungan dengan perjalanan klinis yang buruk dari Covid-19.

Keterbatasan penelitian ini yaitu tidak menganalisis berbagai karakteristik subjek yang digunakan dalam penelitian. Hal ini tidak dilakukan karena tidak semua penelitian mencantumkan secara lengkap karakteristik subjek penelitian.

\section{SIMPULAN}

Gejala gastrointestinal pada pasien Covid-19 memiliki prevalensi yang relatif tinggi, dan sering berupa anoreksia, diare, mual/muntah, dan nyeri perut. Beberapa gejala tersebut berhubungan dengan perjalanan Covid-19 yang berat dan juga hasil RNA positif pada sampel tinja. Gangguan fungsi hati juga turut memperberat gejala tersebut sekaligus menjadi penanda perjalanan klinis yang buruk dari Covid-19.

Bagi penelitian lanjut agar menggunakan laporan penelitian yang mencantumkan karakteristik subjek penelitian pada laporan penelitiannya agar dapat melakukan analisis karakteristik tersebut.

\section{Konflik Kepentingan}

Penulis menyatakan tidak terdapat konflik kepentingan dalam studi ini.

\section{DAFTAR PUSTAKA}

1. Adil T, Rahman R, Whitelaw D, Jain V, AlTaan O, Rashid F, et al. SARS-CoV-2 and the pandemic of COVID-19. Postgrad Med J. 2020;0:1-7. DOI:10. 1136/postgradmedj-2020-138386

2. Tabary M, Khanmohammadi S, Araghi F, Dadkhahfar S, Tavangar SM. Pathologic features of COVID-19: a concise review. Pathol Res Pract. 2020;216(9):153097.

3. Singhal T. A Review of Coronavirus Disease2019 (COVID-19). Indian Journal of Pediatrics. 2020;87:281-6.

4. WHO Coronavirus Disease (COVID-19) Dashboard | WHO Coronavirus Disease (COVID-19). Available from: https:// covid19.who.int/

5. Peta Sebaran | Gugus Tugas Percepatan Penanganan COVID-19. Available from: https://covid19.go.id/peta-sebaran

6. Rokkas T. Gastrointestinal involvement in covid-19: A systematic review and meta-analysis. Ann Gastroenterol. 2020; 33(4):355-65.

7. Holshue ML, DeBolt C, Lindquist S, Lofy KH, Wiesman J, Bruce H, et al. First case of 2019 novel coronavirus in the United States. New Eng J Med. 2020; 382(10):929-36.

8. Parasa S, Desai M, Thoguluva Chandrasekar, V, Patel HK, Kennedy KF, Roesch T, et al. Prevalence of gastrointestinal symptoms and fecal viral shedding in patients with coronavirus disease 2019: a systematic review and meta-analysis. JAMA network open, 2020;3(6):e2011335.

9. Mao R, Qiu Y, He JS, Tan JY, Li XH, Liang J, et al. Manifestations and prognosis of gastrointestinal and liver involvement in patients with COVID-19: a systematic review and meta-analysis. Lancet Gastroenterol Hepatol. 2020;5(7):667-8.

10. Cha MH, Regueiro M, Sandhu DS. Gastrointestinal and hepatic manifestations of COVID-19: a comprehensive review. World Journal of Gastroenterology (WJG). 2020;26(19):2323-32.

11. Cheung KS, Hung IFN, Chan PPY, Lung KC, Tso E, Liu R, et al. Gastrointestinal Manifestations of SARS-CoV-2 infection and virus load in fecal samples from a Hong Kong Cohort: systematic review and meta-analysis. Gastroenterology. 2020;159(1):81-95.

12. Sultan S, Altayar O, Siddique SM, Davitkov P, Feuerstein JD, Lim,JK, et al, AGA Institute Rapid Review of the gastrointestinal and liver manifestations of COVID-19, meta-analysis of international data, and recommendations for the consultative management of patients with COVID-19. Gastroenterology. 2020;159(1):320-34.e27.

13. Velev V, Popov M, Velikov P, Dinkova M, Ilieva V, Gospodinova G, et al. COVID19 and gastrointestinal injury: A brief systematic review and data from Bulgaria. Infezioni in Medicina. 2020; 28(suppl 1):37-41.

14. Kumar VCS, Mukherjee S, Harne PS, Subedi A, Ganapathy MK, Patthipati VS, et al. Novelty in the gut: A systematic review and meta-analysis of the gastrointestinal manifestations of COVID-19. BMJ. 
Open Gastroenterology. 2020;7(1) e000417

15. Zarifian A, Bidary ZM, Arekhi S, Rafiee M, Gholamalizadeh H, Amiriani A et al Gastrointestinal and hepatic abnormalities in patients with confirmed COVID19: A systematic review and metaanalysis. J Med Virol. 2020;Jul 18. Doi: 10.1002/jrmc.26314. Available from: https://doi.org/10.1002/jmv.26314

16. Tariq R, Saha S, Furqan F, Hassett L, Pardi D, Khanna S. Prevalence and mortality of COVID-19 patients with gastrointestinal symptoms: a systematic review and meta-analysis. Mayo Clinic Proceed-ings. 2020;95(8):1632-48. 